\title{
The availability of resting and pupping habitat for the Critically Endangered Mediterranean monk seal Monachus monachus in the archipelago of Madeira
}

\author{
Alexandros A. Karamanlidis, Rosa Pires, Nadia Carina Silva and Henrique Costa Neves
}

\begin{abstract}
In order to describe the resting and pupping habitat of the Critically Endangered Mediterranean monk seal Monachus monachus and facilitate the identification of preferences by the species for suitable habitat for resting and pupping, 94 sea caves in the archipelago of Madeira were located, charted, and categorized using six characteristics. A cluster analysis indicated that there are eight different types of cave, in three groups. Observations of cave usage indicate that monk seals in the archipelago do not appear to exhibit a preference for certain cave types for resting. When taking care of young, however, the species appears to prefer sea caves that
\end{abstract}

have beaches above sea level during high tide and long entrance corridors. Based on these preferences we believe that although there is a large number of caves in the area that are suitable for resting, only $16(17 \%)$ of the caves are suitable for pupping. The survival of the Critically Endangered Mediterranean monk seal will depend on the allocation of sufficient suitable habitat for reproduction.

Keywords Caves, Madeira, marine protected areas, Mediterranean monk seal, Monachus monachus, habitat, pupping.

\section{Introduction}

The Mediterranean monk seal Monachus monachus, is categorized as Critically Endangered on the IUCN Red List, with an estimated 500 individuals surviving in the wild (Johnson, 2000; IUCN, 2003). Habitat loss, direct killing by fishermen, accidental entanglement in fishing gear (Johnson \& Lavigne, 1998) and a mass mortality in 1997 caused by dinoflagellate poisoning and/or a virus epidemic (Costas \& Lopez-Rodas, 1998; Harwood, 1998), have caused monk seal populations to decline steeply and confined the species to four isolated subpopulations. These are located at the Cabo Blanco peninsula of Mauritania, on the archipelago of Madeira in the Atlantic Ocean, the western and eastern Mediterranean, and the Black Sea (Aguilar, 1999).

When on land Mediterranean monk seals frequent sea caves, a behaviour that is believed to be a result of relentless persecution by humans (Pires \& Neves, 2000). Suitable seal shelters usually have one or multiple entrances (underwater or not) leading to a dry surface or beach, of various substrates (sand, pebbles, stones or rock), which

Alexandros A. Karamanlidis Department of Genetics, School of Biology, Aristotle University of Thessaloniki, 54124 Thessaloniki, Greece.

Rosa Pires (Corresponding author), Nadia Carina Silva and Henrique Costa Neves Parque Natural da Madeira (PNM), 9050 Funchal, Madeira, Portugal. E-mail rosapnm@hotmail.com

Received 3 January 2003. Revision requested 19 June 2003. Accepted 5 September 2003. is used for resting and rearing of pups (Neves \& Pires, 1999; Dendrinos \& Dimitropoulos, 2000). Because of the species' elusive nature and the inaccessibility of its habitat, knowledge of the preferences and minimum requirements for resting and pupping has remained limited. Circumstantial evidence indicates that for resting monk seals use caves that protect them from wind and wave action (Neves \& Pires, 1999; Karamanlidis, 2000) and human disturbance (Panou et al., 1993). The species has, however, often been observed to rest in water (Kouroutos, 1987; López-Jurado et al., 1993; Neves \& Pires, 1999) near heavily populated areas and in marginal habitat (Panou et al., 1993; Johnson \& Lavigne, 1999; Güçlüsoy et al., 2002). Pupping in contrast has been recorded mainly in well-protected, isolated caves (Mursaloglu, 1986; Neves \& Pires, 1999; MOm, 2001).

Following a steep decline in the last century, the Mediterranean monk seal in the archipelago of Madeira is now found mainly in the Desertas Islands, a group of three uninhabited islands (Deserta Grande, Bugio and Ilhéu Chão) lying c. $20 \mathrm{~km}$ south-east of Madeira (Fig. 1). In order to protect this species, the Parque Natural da Madeira Service initiated a Monk Seal Conservation and Monitoring Programme in 1988, and in 1990 the Desertas Islands were declared a Nature Reserve. Due to this protection the monk seal colony, which was estimated to number 6-8 individuals in 1984 (Reiner \& dos Santos, 1984), has experienced a remarkable recovery and is now believed to number 23 individuals (Pires \& Neves, 2001). In addition, the species is now occasionally sighted on 

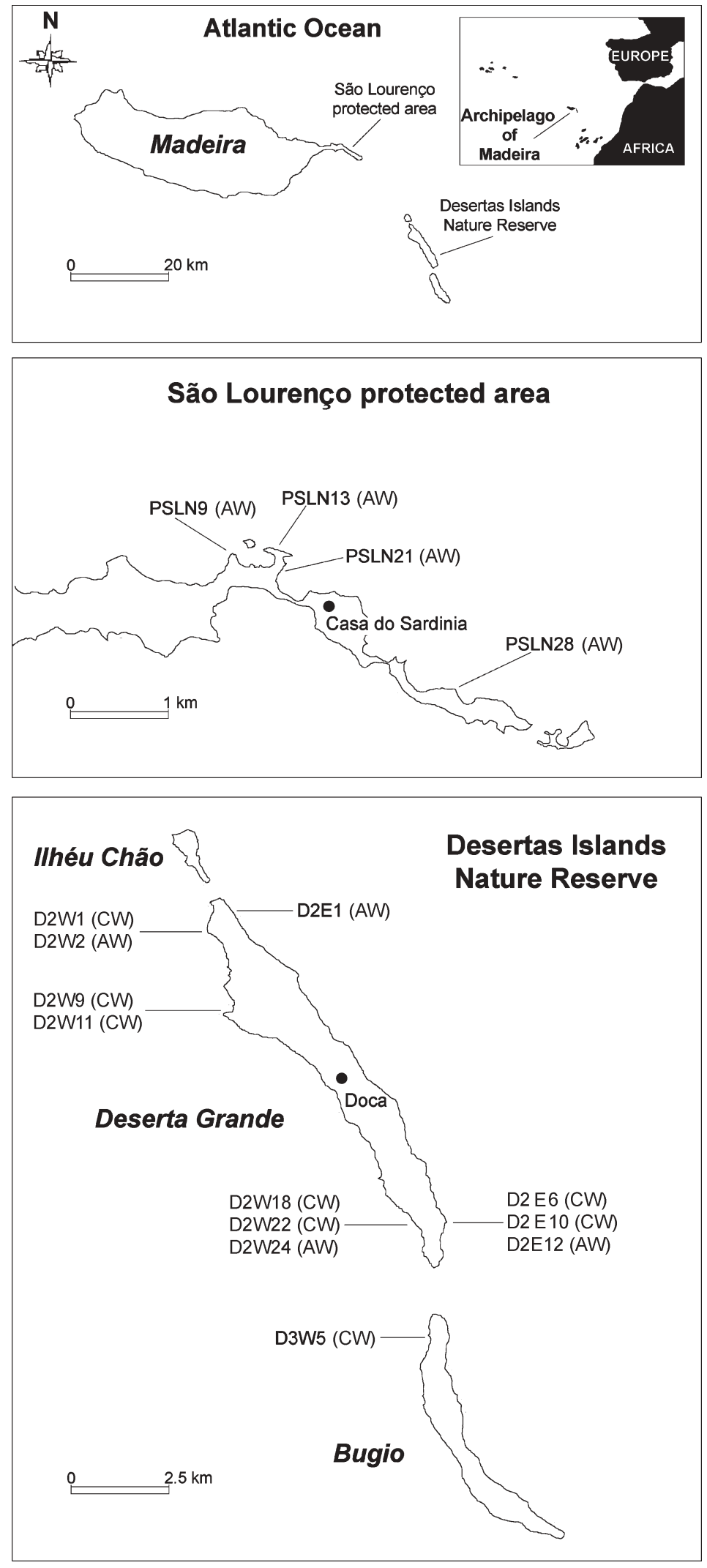

Fig. 1 The location of the Desertas Islands Nature Reserve and the protected area at São Lourenço, in the archipelago of Madeira, with locations of the 16 individually coded caves that we consider offer good pupping conditions under all weather conditions (AW), or good pupping conditions only during calm weather (CW) (see text for details). 
the main island of Madeira (Pires, 2001). The São Lourenço Peninsula, an area at the easternmost tip of Madeira (Fig. 1), which was the last place where monk seals were regularly sighted on Madeira in the past (Melo Machado, 1979), and the adjacent marine area to a depth of $50 \mathrm{~m}$ have been recently included in the Natura 2000 network as a Site of Community Importance.

In order to obtain essential knowledge of the ecology and behaviour of the species in the area, the Parque Natural da Madeira Service initiated a project in the archipelago in 1989 aiming to: (1) locate and chart potential monk seal shelters, (2) describe the habitat of the Mediterranean monk seal and identify the parameters determining the selection of caves as resting or pupping sites, and (3) based on the knowledge of the habitat and the resting and pupping habits of the species in the area, to identify which caves could be used in the future by the recovering monk seal population.

\section{Materials and Methods}

From 1989 to 2001 the entire coastlines of the Desertas Islands Nature Reserve and the protected area at São Lourenço (Fig. 1) were circumnavigated and checked for the presence of suitable monk seal shelters. The warden stations of the Parque Natural da Madeira Service at Doca and Casa do Sardinia on the Desertas Islands and in the protected area of São Lourenço, respectively, were used as bases by the research team, from where an inflatable boat was used for detailed examination of the coastlines. The Desertas Islands Nature Reserve was surveyed in 1989, 1993, 1999 and 2001, and the protected area at São Lourenço was surveyed in 1993 and 2001.

The methodology used for approaching, examining and recording the caves was based on that used in the monk seal monitoring programmes in the eastern Mediterranean (HSSPMS, 1995), modified (Silva, 1999) to suit the particular circumstances encountered in the archipelago. This methodology aimed to minimize disturbance to monk seals by only entering shelters on one occasion (a process that took $<10$ minutes). Caves were entered either by dinghy or snorkelling during low tide, and only after an initial brief inspection ascertained that no animal was present in the cave. The date, time of visit, location, state and features of the caves were recorded. Each cave habitat was described using six characteristics that we considered to be influential in the selection of caves as resting or pupping sites: entrance orientation and size, entrance corridor length, beach area, beach position with respect to high tide, and beach substrate (Table 1).

We performed a cluster analysis on the data, a method that does not involve predefined groups (Sneath \& Sokal, 1973), in order to identify similarities in potential cave habitat between the caves examined. The dendogram of the cluster analysis was produced using Between Groups Linkage and Squared Euclidean Distance (SPSS 9.0 for Windows, SPSS Inc., Chicago, USA).

\section{Results}

Ninety-four sea caves (56 within the Desertas Islands Nature Reserve and 38 in the protected area of São Lourenço) that were considered to be suitable for the species were explored and charted. Adverse weather conditions prevented the surveying of 13 caves in the Desertas Islands Nature Reserve. No systematic surveys to identify caves with underwater entrances have yet been carried out. Several caves that do not have beaches at low tide were not considered in the present analysis, as they were not regarded as suitable monk seal habitat.

The cluster analysis identified eight categories of caves in three groups (Table 2). The two major groups consist of caves that have a beach inside them that is either under

Table 1 Characteristics used to describe potential Mediterranean monk seal cave habitat in the archipelago of Madeira.

\begin{tabular}{ll}
\hline Cave characteristic & Description \\
\hline Entrance orientation & North $\left(316-45^{\circ}\right)$ \\
& South $\left(136-225^{\circ}\right)$ \\
& East $\left(46-135^{\circ}\right)$ \\
& West $\left(226-315^{\circ}\right)$ \\
Entrance size & Small: entrance visible above water at low tide is $<5 \mathrm{~m}^{2}$ \\
& Large: entrance visible above water at low tide is $>5 \mathrm{~m}^{2}$ \\
Entrance corridor & Short: entrance corridor at low tide is $<10 \mathrm{~m}$ long \\
& Long: entrance corridor at low tide is $>10 \mathrm{~m}$ long \\
Beach area inside & Small: $<50 \mathrm{~m}^{2}$ at low tide \\
& Large: $>50 \mathrm{~m}^{2}$ at low tide \\
Beach position inside with respect to high tide state & Underwater: surface of beach is under water at high tide \\
& Above water: surface of beach is above water at high tide \\
Beach substrate & Sand: diameter of predominant substrate is $0.0625-4 \mathrm{~mm}$ \\
& Pebbles: diameter of predominant substrate is $4-256 \mathrm{~mm}$ \\
& Boulders: diameter of predominant substrate is $>256 \mathrm{~mm}$ \\
\hline
\end{tabular}


Table 2 Cave groups and categories identified by the cluster analysis.

\begin{tabular}{lcll}
\hline Group (description) & Category & Number (\%) & Description \\
\hline I (With beach underwater at high tide) & A & $15(16)$ & Large entrance and short entrance corridor \\
& B & $3(3)$ & Small entrance and a long entrance corridor \\
II (With small beach of fine sand) & C & $39(42)$ & Small entrance and short entrance corridor \\
III (With a beach above water at high tide) & D & $11(12)$ & Large entrance and long entrance corridor \\
& F & $2(2)$ & \\
& G & $4(4)$ & Special features, such as double entrances, differentiate \\
& G & $14(15)$ & Shis category from G and H. \\
& H & $6(6)$ & Long entrance corridor \\
\hline
\end{tabular}

(Group I, $\mathrm{n}=68,72 \%$ ) or above (Group III, $\mathrm{n}=24,26 \%$ ) water during high tide. The rare presence of a beach of fine sand in combination with other topographic features led to the distinction of two caves in Group II. One (D2W19) has a beach that is underwater during high tide, whereas the other (D2E12) has a beach that is above water.

The cluster analysis indicated that the variables which had the greatest influence in the formation of the cave categories were the presence or absence of a beach during high tide, the length of the entrance corridor and the size of the entrance. The most common cave category throughout the study area was that of caves with a beach underwater at high tide, a small entrance and a short entrance corridor (Category C, Table 2).

\section{Discussion}

Observations carried out by the Monk Seal Conservation and Monitoring Programme (Neves, 1994; Pires, 1994; Pires, 1997; Silva, 1999; Pires, 2003) indicate that monk seals, when resting, use a wide range of the available habitat, and they have been found to haul out in caves of categories B, D, E, F and H (Table 2). Considering the fact that the species mainly uses caves during low tide (Pires \& Neves, 1998), which is a time when all of the identified caves have a beach above water (depending, however, on the weather conditions), we cannot exclude the possibility that all of the 94 caves are potentially suitable for resting. In the archipelago of Madeira the monk seal appears to be flexible in regard to its minimum requirements for resting, consistent with observations from other parts of the species' distribution range (Dendrinos et al., 1999). The large number of caves available for resting is a beneficial factor for the potential recovery of the species in the area.

Pupping has been recorded in recent years only in three caves, belonging to categories E (D2E12), F (D2W24) and H (D2E1) (Fig. 1 \& Table 2; Neves, 1994; Pires, 1997; Pires, 2003). All three caves have a beach above water during high tide and a long entrance corridor. Caves D2W24 and D2E1 have large beaches within, whereas D2E12 has a small beach. Pupping has also been recorded once in cave D2W18 (Neves, 1994) and suspected to have occurred on a number of occasions in cave D2W22 (Pires, 1997). Despite the fact that both of these caves are classified in category I, i.e. with a beach that is underwater during high tide, their particular features (a small entrance and a long entrance corridor) could provide suitable shelter when the weather is calm and tide amplitude low. The distance of both caves to cave D2W24 and the bay Calhau das Areias, where breeding females have been observed to take care of their young (Pires \& Neves, 2000) lies within the swimming range of monk seal pups (Dendrinos et al., 1999), and the caves could therefore be used as alternative, temporary pupping or resting sites.

Despite the small number of caves that have been observed to be used as pupping sites, and considering the low number of breeding females in the colony, our evidence suggests that females prefer caves with a beach above water during high tide and a long entrance corridor as pupping sites. This evidence is in accordance with knowledge of pupping sites throughout the species range, where the existence of a protected beach during the weaning period is essential for the survival of newborn pups (Dendrinos et al., 1999). Long entrance corridors are of importance because they can act as wave breakers that prevent waves from surging into the cave and sweeping away newborn pups (Mursaloglu, 1986). On this basis, we judge that 16 caves within the study area are potentially suitable for pupping. Twelve caves are located in the Desertas Islands Nature Reserve, and four in the protected area of São Lourenço (Fig. 1). Eight caves were considered to offer good pupping conditions under all weather conditions, whereas the other eight offer good pupping conditions only during calm weather.

Steepness of the beach, which can act as a wave breaker, could also play a significant role in the selection of a cave as a pupping site. As the tide amplitude in the 
area can be up to $2.6 \mathrm{~m}$ (Neves, 1994), only sufficiently steep beaches will remain above water during high tide. Although steepness was not measured in this study it was considered when evaluating caves of category $G$ (Table 2). These caves possess a beach above water during high tide but their entrance corridor is short. Five caves within this group (D2E10, D2W1, D2W11, PSLN21 and D2E6) had beaches that were steep enough to protect a newborn pup during bad weather conditions. However, steepness of a beach can change rapidly due to the mechanical influence of wave action, and therefore we do not consider these caves to be as good for pupping as those with a long entrance corridor.

The habitat available to the Mediterranean monk seal in the archipelago of Madeira is similar to that occupied by the species in other parts of its distribution range. Caves identified usually possess a single entrance above water that leads through an entrance corridor to a beach. Depending on the state of the tide and the nature of the cave, beaches inside are either under or above water during high tide, and covered by sand, pebbles or rocks. Monk seal caves in the archipelago differ in their size, however, from caves utilized by the species in the Northern Sporades of Greece and the Cabo Blanco peninsula in Mauritania. Caves in the Northern Sporades are often smaller than those in Madeira and are not affected by tide, whereas monk seal caves in the Cabo Blanco region are bigger than those in the archipelago of Madeira (R. Pires, H.C. Neves, A.A. Karamanlidis, pers. obs.). Although the cave classification variables used during our survey could be used to identify additional suitable habitat elsewhere on the island of Madeira, in other areas of the species range they should be applied with caution because the resting and pupping habitat of the species is different from that in Madeira.

The potential pupping habitat in the study area represents only $17 \%$ of the cave habitat available to the species. Lack of suitable pupping habitat has been identified as one of the factors preventing the recovery of the monk seal population in the Cabo Blanco region (Marchessaux, 1989). Although lack of such habitat could eventually pose a threat to the recovery of the species in the archipelago of Madeira, it does not appear to do so now. Because of the conservation measures taken to protect the species, monk seals have started to move out of their core area in the Desertas Islands Nature Reserve and also to rest and care for their young on open beaches, thus enlarging the potential pupping habitat (Pires \& Neves, 2000, 2001). The identified potential pupping habitat is located mainly within the Desertas Islands Nature Reserve and particularly on the west coasts of the islands. The prevailing winds in the region originate from the North/North-east (Neves \& Pires, 1999), and therefore caves on the west coast should offer better protection than those on the east coast, and it is likely that the western caves will be used first by the recovering monk seal population.

The survival of the Critically Endangered Mediterranean monk seal will depend on the allocation of sufficient suitable habitat for the continued reproduction of the species. Even in areas with pristine habitat, such as the Desertas Islands and the São Lourenço Peninsula, the proportion of potential pupping habitat is low. This needs to be taken into account when planning the size of future marine protected areas for the species. Although no Mediterranean monk seal births have been recorded for more than 25 years in the protected area of São Lourenço the results of our survey indicate that there are caves suitable for pupping. Considering the occasional presence of the Mediterranean monk seal in this area (Neves, 1994; Pires, 1994) and the results of our survey, the decision to initiate a monk seal monitoring programme in the area, similar to the one carried out at the Desertas Islands Nature Reserve, appears to be well justified (Karamanlidis et al., 2003). We believe that the recent establishment of a Site of Community Importance within the framework of Natura 2000, a network of areas dedicated to the protection of threatened species and habitats, will benefit the conservation of this Critically Endangered species.

\section{Acknowledgements}

We would like to thank Parque Natural da Madeira Service for funding and organizational support, and we express our gratitude to the staff, and particularly the Park Wardens, for their enthusiastic collaboration during this project. We also thank Dr. Martin Jones for his constant encouragement and Dr. Jaume Forcada and three anonymous reviewers for valuable comments on an early draft of the manuscript.

\section{References}

Aguilar, A. (1999) Status of Mediterranean Monk Seal Populations. Aloes Editions, Tunis, Tunisia.

Costas, E. \& Lopez-Rodas, V. (1998) Paralytic phycotoxins in monk seal mass mortality. Veterinary Record, 142, 643-644.

Dendrinos, P. \& Dimitropoulos, A. (2000) The Mediterranean monk seal in Cyprus. The Monachus Guardian, 3, 75-77.

Dendrinos, P., Kotomatas, S. \& Tounta, E. (1999) Monk seal pup production in the National Marine Park of Alonissos-N. Sporades. Contributions to the Zoogeography and Ecology of the Eastern Mediterranean Region, 1, 413-419.

Güçlüsoy, H., Johnson, W.M. \& Karamanlidis, A.A. (2002)

Mediterranean monk seal behaviour. Can we afford to discard anecdotal accounts? The Monachus Guardian, 5, 41-47.

Harwood, J. (1998) What killed the monk seals? Nature, 393, $17-18$.

HSSPMS (1995) Continuation of the Monitoring of the Monk seals in the National Marine Park of Northern Sporades. Final Report for the European Commission Project 4-3010(92)7829.

Unpublished Report, Athens, Greece. 
IUCN (2003) 2003 IUCN Red List of Threatened Species. IUCN, Gland, Switzerland [http:/ / www.redlist.org, accessed 24 November 2003].

Johnson, W.M. (ed.) (2000) The numbers game. The Monachus Guardian, 3, 5.

Johnson, W.M. \& Lavigne, D.M. (1998) The Mediterranean Monk Seal. Conservation Guidelines. International Marine Mammal Association, Guelph, Canada.

Johnson, W.M. \& Lavigne, D.M. (1999) Monk seals in antiquity. The Mediterranean monk seal (Monachus monachus) in ancient history and literature. Mededelingen, 35, 1-101.

Karamanlidis, A.A. (2000) Monitoring human and Mediterranean monk seal activity in the National Marine Park of Alonnissos and Northern Sporades, Greece. The Monachus Guardian, 3, 31-34.

Karamanlidis, A.A., Pires, R., Neves, H.C. \& Santos, C. (2003) The habitat of the endangered Mediterranean monk seal at the São Lourenço peninsula - Madeira. Aquatic Mammals, 29, 400-403.

Kouroutos, V. (1987) The Mediterranean Monk Seal in the National Park of the Northern Sporades 1982-1987. BSc thesis, School of Natural Sciences, University of Athens, Greece.

López-Jurado, L.F., González, L.M., González, J.R., Grau, E., Félix, M.S. \& Aguilar, A. (1993) Le phoque moine (Monachus monachus) sur les côtes du Sahara occidental - Mauritanie: dernierès données Biologiques et Mortalite entre 1988-1993. In Abstracts of the Convention on the Conservation of European Wildlife and Natural Habitats. Euro-African Seminar on Cooperation on Nature Conservation with North and North-west Africa, Dakar, Senegal, 21-24 June 1993. T-PVS, (93)23, 24-40, Council of Europe, Strasbourg, France.

Marchessaux, D. (1989) Recherches sur la Biologie, l'Ecologie et le Statut du Phoque Moine, Monachus monachus. GIS Posidonie Publications, Marseille, France.

Melo Machado, A.J. (1979) Os Lobos Marinhos (Genero Monachus, Fleming 1822). Museu do Mar, Unidade de Mamalogia, Cascais, Portugal.

MOm (2001) Conservation on the Front Line: Guarding Critically Endangered Mediterranean Monk Seals in the Sporades Marine Park. Annual Activity Report to the International Fund for Animal Welfare. Unpublished Report, Athens, Greece.

Mursaloglu, B. (1986) Pup-mother-environment relations in the Mediterranean monk seal, Monachus monachus (Hermann, 1779), on Turkish coasts. Communications of the Faculty of Science of the University of Ankara, Series C, 4, 1-8.

Neves, H.C. (1994) Six Years of Protection and Monitoring of the Monk Seal (Monachus Monachus) in the Archipelago of Madeira. Parque Natural da Madeira, Madeira, Portugal.

Neves, H.C. \& Pires, R. (1999) O Lobo Marinho no Arquipelago da Madeira. Parque Natural da Madeira Madeira, Portugal.

Panou, A., Jacobs, J. \& Panos, D. (1993) The endangered Mediterranean monk seal Monachus monachus in the Ionian Sea, Greece. Biological Conservation, 64, 129-140.

Pires, R. (1994) Observações de Lobos-Marinhos (Monachus monachus (Hermann, 1779)) nas Ilhas Desertas e Estudo da Sua Ocorrência na Ponta de São Lourenço - Ilha da Madeira. BSc thesis, University of Algarve, Algarve, Portugal.
Pires, R. (1997) Estado actual e aspectos da biologia e ecologia da colónia de lobos marinhos, Monachus monachus, das Desertas Islands. Unpublished Report, Secretaria da Agricultura Florestas e Pescas. Parque Natural da Madeira, Funchal, Portugal.

Pires, R. (2001) Are monk seals recolonising Madeira Island? The Monachus Guardian, 4, 34-36.

Pires, R. (2003) Reproductive parameters of the endangered Mediterranean monk seal, Monachus monachus, at the Desertas Islands - Madeira Archipelago. MSc thesis, Manchester Metropolitan University, Manchester, United Kingdom.

Pires, R. \& Neves, H.C. (1998) Influence of gradient tides on the monk seal activity Monachus monachus, on Calhau das Areias bay in Deserta Grande - Madeira Archipelago. In Abstracts of the III Symposio Fauna e Flora das Ilhas Atlanticas, Ponta Delgada/Açores, Portugal, 21-25 September 1998, p. 268.

Pires, R. \& Neves, H.C. (2000) Monk seal sightings on open beaches in Desertas Islands - Madeira Archipelago. In Abstracts of the 14th Annual Conference of the European Cetacean Society, Cork, Ireland, 2-5 April 2000, p. 19. European Cetacean Society \& Cambridge University Press, Cambridge, UK

Pires, R. \& Neves, H.C. (2001) The Desertas Islands Nature Reserve: a home for the Mediterranean monk seal, Monachus monachus. In 15th Annual Conference of the European Cetacean Society, Rome, Italy, p. 28. European Cetacean Society \& Cambridge University Press, Cambridge, UK.

Reiner, F. \& dos Santos, M. (1984) L'Extinction imminente du Phoque moine de Madere. In Second International Conference on the Monk Seals, La Rochelle/France. Annales de la Société des Sciences Naturelles de la Charente-Maritime, La Rochelle, France, Supplement, pp. 79-87.

Silva, N. C. (1999) Caracterização do Habitat e Distribuição Espacio-temporal do Lobo-marinho, Monachus monachus, nas Ilhas Desertas. BSc thesis, Faculty of Science, University of Lisbon, Portugal.

Sneath, P.H.A \& Sokal, R.R. (1973) Numerical Taxonomy. Freeman, San Francisco, USA.

\section{Biographical sketches}

Alexandros Karamanlidis is working on the ecology, conservation and management of threatened mammals of the Mediterranean region. He is currently involved in a study of the behaviour and conservation genetics of brown bears in Greece.

Rosa Pires' main research interests focus on the conservation of threatened species and management of protected areas in Madeira. She is currently carrying out a study on the reproductive parameters and social organization of the Mediterranean monk seal.

Nadia Carina Silva's main research interest is the conservation of Madeiran flora and fauna, and she is actively involved in environmental education in Madeira.

Henrique Costa Neves has been the Director of the Parque Natural da Madeira for many years, and was the initiator of the Monk Seal Conservation and Monitoring Programme. He is currently involved in the environmental policy of the Municipality of Funchal, Madeira. 